\title{
"STANDS SCOTLAND WHERE IT DID?": DEVOLUTION, HUMAN RIGHTS AND THE SCOTTISH CONSTITUTION SEVEN YEARS ON
}

\author{
Aidan O'Neill QC \\ "Macduff: Stands Scotland where it did? \\ Ross: Alas, poor country! Almost afraid to know itself."
}

Macbeth Act IV Scene iii

\section{Introduction}

\section{The Caledonian antisyzygy}

Scotland is, according to an on-going publicity campaign promoted by the Scottish Ministers "the best (small) country in the world". According to the World Health Organisation, however, Scotland has the second highest homicide rate in Western Europe (only Finland's is higher). ${ }^{1}$ The Scottish Executive's own statistics record an average and consistent homicide rate over the past twenty years or so of 22 violent deaths per million of population, ${ }^{2}$ and press reports point out that an individual is two to three times more likely to be murdered in Scotland than in England and Wales. ${ }^{3} \mathrm{~A}$ study from the University of California is expected to claim that Scotland's homicide rate is higher than that in the United States, in Israel, in Uzbekistan, in Chile and in Uruguay. Another recent United Nations Report has described Scotland as the most violent country in the developed world on the basis of the report's estimate of some 2,000 people each week being the subject of violent attack. ${ }^{4}$ And research from the London School of Hygiene and Tropical Medicine indicates that Scotland now has one of the highest mortality rates in Western Europe for cirrhosis of the liver attributable to alcohol abuse. 5 Meanwhile the Scottish Ministers make plans to give Scotland a prison capacity of 8,000 which, if filled, would give Scotland the highest prison population rate in Western Europe. This mismatch between aspiration and experience - "it is the best of countries; it is the worst of countries" - exemplifies the Caledonian antisyzygy.

Antisyzygy means the yoking together of contradictory impulses or drives existing simultaneously, be it: love and hate; arrogance and abjection; radicalism and reaction; realism and fantasy. This idea of an internal (and eternal) conflict within the one entity has long been said to capture

1 See www.who.int/whosis.

2 See http://www.scotland.go vuk/stats/bulletins/00377-01.asp for the Government official statistics showing homicide rates in Scotland from 1984 to 2004.

3 See, for example, The Guardian 26 September 2005 "Scotland has the second highest murder rate in Europe" archived at http://www.guardian.co.uk/crime /article/0,2763,1578388,00.html.

4 See http://www.timesonline.co.uk/article/0,,2-1786945,00.html.

5 See, for example, The Independent 6 January 2006 "Binge drinking blamed for increase in liver cirrhosis across Britain" archived at http://news.independent. co.uk/uk/health_medical/article336782.ece. 
something of the peculiarly Scottish character and situation and is, perhaps, archetypically to be seen in the novel The Strange Case of Dr. Jekyll and Mr. Hyde, a work of the Edinburgh lawyer, Robert Louis Stevenson. ${ }^{6}$ But it is, I suggest, a useful (if somewhat literary) trope with which to begin to appreciate the impact and development of a human rights culture in Scotland and Scotland's relationship within the United Kingdom in recent years.

In so far as one can capture these things, it might be said that what has been most characteristic of Scotland's constitutional and legal history to date is that of being in a state of constant unresolved and irresoluble tension, of attachment and separateness, of rejection and belonging. The dynamic is one of seeking to accommodate the political and geographical reality of union with England - a country with ten times as many people - while striving to maintain a sense of Scotland as still being a distinct nation within a unitary State. Scotland, it must always be borne in mind, is a small country of some 5 million people - and dropping. There remains, then, a tension in the Scottish legal system between the assertion and preservation of its independent history within the civilian European Roman law tradition, and the sometimes resented pull toward the English common law. This tension makes for the odd mixture of judicial attitudes of conservatism and radicalism, of parochialism and crabbed insularity counterbalanced, at times, by a generous internationalism in approach.

\section{The Devolutionary Settlement in Scotland}

The gradual dismantling of the British Empire in the course of the $20^{\text {th }}$ century and the pooling of the sovereignty of the United Kingdom with other member States of the European Union led to increasing political pressure within Scotland for an effective re-negotiation of the terms of the 1707 Parliamentary Union with England. The end result of that re-negotiation was the Scotland Act 1998 which established a new Scottish Parliament and an executive drawn from its ranks - the Scottish Ministers - who would, in effect, govern Scotland's internal affairs. The Scottish Ministers were also bound (under Section $58 \mathrm{SA}$ ) to respect and, if necessary, implement, all and any other international obligations of the United Kingdom. ${ }^{7}$ But legislative and administrative power under this scheme was (provisionally) devolved and never (permanently) ceded to the new Parliament and Executive.

6 See: Gregory Smith Scottish Literature: Character and Influence. London: Macmillan, 1919 and Hugh MacDiarmid "The Caledonian Antisyzygy and the Gaelic Idea" (1931-32) in Selected Essays of Hugh MacDiarmid edited by D. Glen. (London: Jonathan Cape, 1969) at pp.56-74.

7 See, too, para.7 of Sch.5 to the Scotland Act which provides as follows:

International relations, including relations with territories outside the United Kingdom, the European Communities (and their institutions) and other international organisations, regulation of international trade and international development assistance and co-operation are reserved matters.

Sub-paragraph (1) does not reserve - observing and implementing international obligations, obligations under the Human Rights Convention and obligations under European Community law, assisting Ministers of the Crown in relation to any matter to which that sub-paragraph applies. 
The 1998 devolutionary settlement may be seen as an attempt to resolve historic Anglo-Celtic tensions within the United Kingdom, by giving formal recognition to the separateness of Scotland (as well as to the distinctiveness of Wales and Northern Ireland). But no provision is made for the constitutional recognition of England as a distinct entity within the Union. England is left to be governed by the institutions of the United Kingdom. This results in a new tension - the "West Lothian question" - because while the English are deprived of a say in the internal affairs of Scotland, Scots MPs (i) continue to vote in Westminster on purely English matters and (ii) to act as Secretaries of State over Whitehall departments dealing with purely English affairs. In theory of course, the UK Parliament's sovereignty remained untouched in the new constitutional framework. Westminster retains the right to legislate in all matters affecting Scotland, not simply in those areas it specifically reserved to itself in Schedule 5 to the Scotland Act. As has been observed, and as repeated re-imposition of direct rule in Northern Ireland even after the enactment of the Northern Ireland Act 1998 shows, power devolved is power retained.

The devolution statutes have created non-sovereign democratic institutions. These institution have strict legal limits on the extent of their powers, and provision is made for those limits to be enforced by the courts. This itself is the cause of new tension within the devolved polity. The Scottish Parliament may look and act like a Parliament, but in law it has no more status than any other statutory body exercising powers within its limited jurisdiction. This point was forcefully made by Lord Rodger of Earlsferry, when Lord President of the Court of Session, when he stated

"[T]he [Scottish] Parliament [i]s a body which - however important its role - has been created by statute and derives its powers from statute. As such, it is a body which, like any other statutory body, must work within the scope of those powers. If it does not do so, then in an appropriate case the court may be asked to intervene and will require to do so, in a manner permitted by the legislation. In principle, therefore, the Parliament like any other body set up by law is subject to the law and to the courts which exist to uphold that law ....

While all United Kingdom courts which may have occasion to deal with proceedings involving the Scottish Parliament can, of course, be expected to accord all due respect to the Parliament as to any other litigant, they must equally be aware that they are not dealing with a Parliament which is sovereign: on the contrary, it is subject to the laws and hence to the courts. For that reason, I see no basis upon which this court can properly adopt a 'self-denying ordinance' which would consist in exercising some kind of discretion to refuse to enforce the law against the Parliament or its members. To do so would be to fail to uphold the rights of other parties under the law."

${ }^{8}$ Whaley and others $\mathrm{v}$ Lord Watson of Invergowrie and The Scottish Parliament 2000 SC 125, OH; 2000 SC 340, IH per Lord Rodger at 348H, 350B-C. 
And while Section 38(1) of the Crown Proceedings Act 1947 now defines "officer" in relation to the Crown as including "a Minister of the Crown or a member of the Scottish Executive", the courts have rejected the Scottish Ministers' claims to be entitled to the respect and immunities traditionally afforded "the Crown". As the First Division has noted:

"[I]t is clear that the powers of the respondents [the Scottish Ministers], who were created by the statute, are circumscribed both by the limits of devolved competence and by reference to compatibility with Convention rights and community law. The validity of the acts of the respondents may be determined by a court of law as a devolution issue. In this respect the respondents may be compared with the Scottish Parliament, which is not sovereign but is subject to the laws and hence to the courts (Whaley v Watson 2000 S.C. 340, Lord President Rodger at page 350$)$. In the present case we are concerned with the exercise by the respondents of their statutory functions under the Prisons (Scotland) Act 1989. While the exercise of such statutory functions on behalf of Her Majesty is devolved to the Scottish Ministers, it is erroneous, in our view, to regard proceedings against them in respect of any of those functions as proceedings against the Crown itself."

\section{Models for fundamental rights protection under the constitution}

In Matadeen v Pointu Lord Hoffmann drew a contrast between the traditional UK constitutional approach, under which Parliament was regarded as sovereign in all matters, and countries in which fundamental rights were entrenched within a written constitution, noting:

"A self-confident democracy may feel that it can give the last word, even in respect of the most fundamental rights, to the popularly elected organs of its constitution. The United Kingdom has traditionally done so; perhaps not always to universal satisfaction, but certainly without forfeiting its title to be a democracy. A generous power of judicial review of legislative action is not therefore of the essence of a democracy. Different societies may reach different solutions.

The United Kingdom theory of the sovereignty of Parliament is however an extreme case. The difficulty about it, as experience in many countries has shown, is that certain fundamental rights need to be protected against being overridden by the majority. No one has yet thought of a better form of protection than by entrenching them in a written constitution enforced by independent judges. Even the United Kingdom is to adopt a modified form of judicial review of statutes by its incorporation of the European Convention." 10

The problem which the devolutionary settlement in Scotland has introduced - compounding the Caledonian antisyzygy - is that within the one unitary

\footnotetext{
${ }^{9}$ Beggs v Scottish Ministers, 2005 SLT 305, IH at para.24.

10 Matadeen v Pointu [1999] AC 98 per Lord Hoffmann at 109-110.
} 
State of the United Kingdom we now have two wholly divergent constitutional models in relation to the protection of fundamental rights. One model under the Human Rights Act 1998 - which received Royal Assent on 9 November 1998 - is based on the idea of delicate constitutional dialogue and a dance of deference between judiciary and legislature but one where ultimately Parliament has the last word. The other model, under the Scotland Act - which received Royal Assent on 19 November 1998 - is one in which the courts are supreme and are required to strike down all and any "unconstitutional" acts of the devolved legislature and administration. The fact that these two UK statutes are working on the basis of quite distinct democratic models becomes clearer from an examination of the structures of the two acts and how they have been applied in practice.

\section{The Human Rights Act and constitutional dialogue}

The scheme of the Human Rights Act is one which may be said to be based along the lines of the model proposed by Sir Stephen (now Lord Justice) Sedley in which he speaks of:

"a new and still emerging constitutional paradigm, no longer Dicey's supreme Parliament . . . but a bi-polar sovereignty of the Crown in Parliament and the Crown in the courts, to each of which the Crown Ministers are answerable - politically to Parliament and legally to the courts." 11

Section 3(1) HRA obliges public authorities, so far as it is possible to do so, to read legislation in a way which is compatible with Convention rights and to give effect to that legislation in a way which is compatible with those rights. ${ }^{12}$ Where it is not possible to read or apply an Act of the Westminster Parliament in a manner which is compatible with Convention rights, Section 3(2)(b) HRA provides that the legislative provisions in question remain fully valid, operative and enforceable: in contrast to the situation where there is an incompatibility with Community law, national courts are not empowered even after incorporation of the Convention to "dis-apply" or suspend primary statutory provisions which contravene human rights.

Section 4 HRA sets up a mechanism for dialogue between the courts and the legislature in the event of an unavoidable conflict between the Convention rights and an Act of Parliament by giving the courts the power to make a declaration as to the incompatibility of this provision with the requirements of the European Convention. This conversation may at times be a spirited one. ${ }^{13}$ But any such declaration of incompatibility by the courts has, by

11 Sir Stephen Sedley "Human Rights: a twenty-first century agenda" [1995] Public Law 386 at 389. See, too, the judgment of Sedley J. in $R$ v Parliamentary Commissioner for Standards, ex parte Al-Fayed [1998] 1 WLR 669 at 670 where he describes the relationship between the courts and Parliament as "a mutuality of respect between two constitutional sovereignties".

${ }^{12}$ See Ghaidan v Godin-Mendoza [2004] 2 AC 557 per Lord Rodger of Earlsferry at para.107 p.595.

13 See, for example, A v Secretary of State for the Home Department [2005] AC 68, per Lord Bingham of Cornhill at 110-1 para.42:

"I do not ... accept the distinction which [the Attorney General] drew between democratic institutions and the courts. It is of course true that the judges in this country are not elected and are not answerable to Parliament. It is also of course 
virtue of Section 4(6)(a) HRA, no effect on the validity, continuing operation or enforceability of the offending legislative provision. Further, Section 4(6)(b) HRA provides that any declaration of incompatibility is not binding on the parties to the proceedings in which it is made. The obtaining of a declaration of incompatibility will therefore be a Pyrrhic victory for the party in whose favour it is granted unless Parliament decides to change the relevant legal provisions with retrospective effect so as to apply in his case. A final declaration of incompatibility - that is one against which no right of appeal exists or is being exercised - gives Ministers of the Crown the power to order under Section 10(1) HRA such amendment to, or repeal of, the primary or secondary legislation in question as they think is appropriate to remove the incompatibility. Any such remedial order will require the approval of Parliament under the affirmative resolution procedure, all as set out in Schedule 2 to the Act. The principle of ultimate Westminster Parliamentary sovereignty is said thereby to be maintained. As Lord Irvine of Lairg has stated:

"This innovative technique will provide the right balance between the judiciary and [the Westminster] Parliament. [The Westminster] Parliament is the democratically elected representative of the people and must remain sovereign. The judiciary will be able to exercise to the full the power to scrutinise legislation rigorously against the fundamental freedoms guaranteed by the Convention but without becoming politicised. The ultimate decision to amend [primary Westminster] legislation to bring it into line with the Convention, however, will rest with [the Westminster] Parliament. The ultimate responsibility for compliance with the Convention must be [the Westminster] Parliament's alone." $" 14$

true ... that Parliament, the executive and the courts have different functions. But the function of independent judges charged to interpret and apply the law is universally recognised as a cardinal feature of the modern democratic state, a cornerstone of the rule of law itself. The Attorney General is fully entitled to insist on the proper limits of judicial authority, but he is wrong to stigmatise judicial decision-making as in some way undemocratic. . . . The Human Rights Act 1998 gives the courts a very specific, wholly democratic, mandate. As Professor Jowell has put it 'The courts are charged by Parliament with delineating the boundaries of a rights-based democracy' ('Judicial Deference: servility, civility or institutional capacity?' [2003] PL 592, 597).”

And per Lord Hoffmann at 132 para.97:

"[T] he power of detention [under s.23 of the Anti-terrorism, Crime and Security Act 2001] is at present confined to foreigners and I would not like to give the impression that all that was necessary was to extend the power to United Kingdom citizens as well. In my opinion, such a power in any form is not compatible with our constitution. The real threat to the life of the nation, in the sense of a people living in accordance with its traditional laws and political values, comes not from terrorism but from laws such as these. That is the true measure of what terrorism may achieve. It is for Parliament to decide whether to give the terrorists such a victory."

14 Lord Irvine of Lairg "The Development of Human Rights in Britain under an incorporated Convention on Human Rights" [1998] Public Law 221-236 at 225. 
But Section 21 HRA specifically includes Acts of the Scottish Parliament ("ASPs") within the definition of "subordinate legislation" which means that any ASP which is incompatible with any of the Convention rights is impliedly repealed under the HRA to the extent of its incompatibility. And no provision of primary Westminster legislation can be prayed in aid to prevent such implied repeal of Scottish legislation since the governing Westminster Statute is the Scotland Act 1998.

\section{Convention rights and the limits on devolved power}

The Scotland Act has been described as "a major constitutional measure which altered the government of the United Kingdom". ${ }^{15}$ It contains quite different constitutional checks and balances from those which form the basis of the Human Rights Act. ${ }^{16}$ The system under the Scotland Act is predicated on a wholly different constitutional model; one in which judges - rather than the legislature - have the last word.

Section 29(1) SA states that "an Act of the Scottish Parliament [ASP] is not law so far as any provision of the Act is outside the legislative competence of the [Scottish] Parliament". Not only is it put beyond the legislative competence of the Edinburgh Parliament or Executive to pass laws in areas reserved to the Westminster Parliament, but the Scotland Act also provides (in Section 29(2)(d) SA) that the Scottish Parliament has no power to pass any Act which contains a provision which is incompatible with any of the Convention rights specified in Schedule 1 to the Human Rights Acts 1998.

Statutory functions and functions derived from the royal prerogative may be conferred upon and exercised by the Scottish Ministers insofar as the exercise of these functions are compatible with the limits imposed on the legislative competence of the Scottish Parliament: see Section 53 SA. It follows from this that it falls outside the Scottish Ministers' devolved competence to confirm, approve or make any provision by subordinate legislation which would be incompatible with Convention rights: see Section 54 SA. Although Section 63 SA on its face allows for the transfer (by Order in Council) to the Scottish Ministers of further powers or functions which may exceed the legislative competence of the Scottish Parliament, this transfer cannot be used as a means to allow the Scottish Ministers to act incompatibly with Convention rights. This is confirmed by the provisions of Section 57(2) SA which states that "a member of the Scottish Executive has no power to make any subordinate legislation or to do any other act, so far as the legislation or act is incompatible with any of the Convention rights."

The protection of Convention rights under the constitutional settlement set out in the Scotland Act is, then, embedded within the concept of limits on the

$15 R$ v HM Advocate 2003 SC (PC) 21 per Lord Rodger of Earlsferry at 60 para.16.

16 See Somerville and others v Scottish Ministers [2005] CSOH 23 per Lady Smith at para.51: "[T] here is a clear constitutional framework within the Scotland Act to deal with the situation where a member of the public claims that a Scottish Minister has failed in his constitutional obligation to act in accordance with the Convention and it contains a self contained system of checks and balances which do not apply to claims under the Human Rights Act. It is impossible to resist the conclusion that Parliament intended the two types of claim to be treated differently." 
powers or competence of the devolved authorities. Thus, the Convention compatible interpretative obligation for UK legislation in Section 3 HRA is paralleled by an interpretative obligation for Scottish legislation in Section 101 SA, relative to competence: Section 101(2) SA enjoins the courts when faced with devolved Scottish primary and subordinate legislation which could be read in such a way as to be outside competence to read the provision "as narrowly as possible as is required for it to be within competence, if such a reading is possible" and to give effect to it accordingly.

And the "implicit dialogue" provisions between court and legislature set out in Section 4 HRA in relation to Westminster legislation has its parallel in Section 102 SA as regards Scottish legislation: Section 102(2)(a) SA permits the court to remove or limit the retrospective effect of any finding that legislation - whether passed by the Scottish Parliament or the Scottish Ministers - is beyond their legislative competence and hence ultra vires; and Section 102(2)(b) SA allows the court to suspend the effect of its decision on lack of legislative vires for such period and on such conditions as might allow the defect identified by it to be corrected by the legislature.

Significantly there is no such power or discretion vested in the courts in relation to administrative (non-legislative) acts of the Scottish devolved institutions, just as there is no discretion given to the courts under Section 6 HRA to permit public authorities to act in a manner which is Convention incompatible - Section 6(2) HRA requires any such authorization to be found in the provisions of primary Westminster legislation. By contrast, the Scotland Act provisions have unequivocally placed the ultimate responsibility for ensuring compliance with the Convention in Scotland with the judges, rather than with the democratically elected Scottish Parliament or the publicly accountable Scottish Ministers.

In its decision in $R$ v HM Advocate the Privy Council - acting under its devolution jurisdiction - made it clear that the Scotland Act has to be read as a constitutional document which provides, within its four corners, a complete system of rights, obligations and remedies as regards the devolved governance of Scotland. Thus, the Judicial Committee held that Section 100(1) SA rather than Section 7 HRA is the proper statutory basis for any claim against the Scottish devolved authorities in respect of a claimed breach of Convention rights; and Section 100(3) SA rather than Section 8 HRA is the basis for claims seeking "just satisfaction" damages for breach by the Scottish authorities of Convention rights. ${ }^{17}$ If the coherence of the Scottish devolved constitutional settlement as set out in the Scotland Act is to be preserved, the provisions of the Scotland Act regarding the protection of Convention rights must take precedence over the parallel provisions of the Human Rights Act when considering questions of the Convention compatibility of Scottish legislation and Scottish Ministerial action. ${ }^{18}$ Any

$17 R$ v HM Advocate 2003 SC (PC) 21 per Lord Hope of Craighead at 39-40, 42 paras.29, 38; per Lord Rodger of Earlsferry at 61-62 paras.17-19.

18 One may note in this regard Lord Hardie when, as Lord Advocate, promoting the Scotland Bill through the House of Lords (HL Hansard 2 November 1998, Column 79): "[It] is intended to bring the Scotland Bill more into line with the Human Rights Bill in certain limited respects. It is not intended that the Scotland 
resulting difference between the position in Scotland and that which may exist in England under the Human Rights Act 1998 may be said to be a difference which has been prescribed by the UK Parliament in the express enactment of these provisions of the Scotland Act relating to Convention rights protection in the context of limits on competency of the devolved authorities.

\section{No discretion as to remedy under the Scotland Act}

Thus whereas under Section 8(1) HRA the courts are given a discretion as to what remedy, if any, to afford an individual whose Convention rights have been violated by a public authority, ${ }^{19}$ there is no such discretion where the courts have found that the Scottish Ministers have acted in a manner which is incompatible with Convention rights. This is because the courts have held that the effect of Section 57(2) SA is to deprive the Scottish Ministers of all power to act incompatibly with Convention rights and therefore any purported act in contravention of a Convention right is ultra vires. ${ }^{20}$ Accordingly under the scheme of the Scotland Act, it is simply not open to either the Scottish Parliament or the Scottish Ministers to decide to maintain Convention incompatible legislation in force, and they have no right to amend the legislation in such manner as they think fit. Instead any Convention incompatible legislation is to be struck down by the courts, whatever the wishes of the legislature or administration. The Westminster legislature has given the courts no choice as to what the consequences of any particular violation by the Scottish devolved administration or parliament of an individual's Convention rights by them should be. Such Convention incompatible action is void and, in principle, of no effect, not only in relation to the particular individual establishing violation of his or her rights, but contra mundum.

As has been observed, within the context of the devolved Scottish constitution the judiciary have therefore been handed rather different

Bill should be brought so completely into line with the Human Rights Bill that it destroys the common procedures for dealing with devolution issues no matter in which legal proceedings they arise and for determination ultimately by the Judicial Committee [of the Privy Council]."

19 Attorney-General's Reference (No 2 of 2001) [2004] 2 AC 72 per Lord Rodger of Earlsferry at p.132 para.175: "These provisions [of section 8 HRA] indicate that the courts are meant to mould their remedies for unlawful acts to fit in with the requirements of the Convention. By contrast, there is nothing to suggest that Parliament ever intended that under the Human Rights Act 1998 the British courts should be obliged to grant a specific remedy for a particular kind of violation where that remedy was not specified by the Convention or where that remedy would not be just and appropriate in the circumstances."

20 Dyer v Watson, 2002 SC (PC) 89 per Lord Millett at para.131:

"[T] he European Court [of Human Rights] . . . is not obliged to grant a remedy once a breach of a Convention right has been established; [n]or in England, where the court has a discretion to make such order as it 'considers to be just and appropriate'. But . . . in Scotland . . . Section 57(2) of the Scotland Act 1998 imposes a vires control by providing that the Lord Advocate has no power to act in a way which is incompatible with an accused's Convention rights. If the Lord Advocate threatens to exceed his powers, there is no discretion to withhold a remedy". 
constitutional tools from those provided to the judges under the Human Rights Act. The Scotland Act's insistence on vires control of the Convention incompatible acts of the devolved authorities might be criticized insofar as it prevents the judges from "fashion[ing], more carefully than ever, solutions taking into account the sometimes complementary and sometimes opposing concerns of fairness to the individual, societal interests, and the integrity of the judicial system". ${ }^{21}$ But, as Lord Rodger of Earlsferry has noted:

"In enacting a constitutional settlement of immense social and political significance for the whole of the United Kingdom, Parliament has itself balanced the competing interests of the Government of the United Kingdom, of the Scottish Executive, of society and of the individuals affected. Having done so, Parliament has decided that members of the Scottish Executive should have no power to do acts that are incompatible with any of the Convention rights. ... If this is to use an axe rather than a scalpel, then Parliament has selected the tool. Your Lordships' Board cannot re-open the exercise that Parliament undertook and re-balance the competing interests for itself. Rather, it must loyally give effect to the decision of Parliament on this sensitive matter, even if - or perhaps especially if there are attractions in a different solution ..."22

\section{Scotland Act as lex specialis}

As we have noted, the Convention rights' limits on the powers of the Scottish Parliament and Scottish Ministers exist independently from the provisions of the Human Rights Act. ${ }^{23}$ Indeed, any person seeking to rely on his Convention rights against the Scottish Ministers or Scottish Parliament is not entitled to pick and choose between the remedies and procedures provided specifically in relation to the Scottish devolved authorities under Scotland Act and those applicable to public authorities in general under the Human Rights Act. Any Convention rights based challenges to the acts of the Scottish devolved administration or legislature have to be raised as

21 This is the description of the judge's role under the Canadian Charter of Rights and Freedoms by L'Heureux-Dubé J in $R$ v $O^{\prime}$ Connor [1995] 4 SCR 411 at p.461 para.69 which is quoted with approval by Lord Steyn in H.M. Advocate v $R 2003$ SC (PC) 21 at 30 para.18 who then continues: "The moral authority of human rights in the eyes of the public must not be undermined by allowing them to run riot in our justice systems. In working out solutions under the Scotland Act 1998 and the Human Rights Act 1998 courts in Scotland and England should at all times seek to adopt proportionate remedies. In my view there is nothing in the opentextured language of s.57(2) SA, read in context, which rules out the application of such an approach in this case."

${ }^{22}$ H.M. Advocate v R 2003 SC (PC) 21 per Lord Rodger of Earlsferry at 73 para.50.

23 See Clancy v Caird, 2000 SC 441, IH per Lord Penrose at 473, para.9 of his judgment: "Section 57(2) SA is concerned with a further specific limitation on the powers of the [Scottish] Executive expressed by reference to the Convention and Community law. It is not a temporary or transitional provision. It will continue to apply after the Human Rights Act comes fully into force." 
"devolution issues" and brought under and in terms of the Scotland Act. ${ }^{24}$ This has the following important procedural consequences among others:

(i) the Convention rights challenge to devolved action has to be intimated to the relevant law officer or officers for the jurisdiction of the UK in which the proceedings in question take place; ${ }^{25}$

(ii) the courts are enjoined to consider whether and to what extent any decision on Convention incompatibility of devolved legislation (but not administrative action) should be made retrospective; ${ }^{26}$

(iii) the court may also suspend its judgment to allow the identified Convention incompatibility in devolved legislation to be corrected $;^{27}$

(iv) procedure is made for lower courts to make Article 234 EC style "preliminary references" on such Convention rights challenges to the superior courts; ${ }^{28}$ and

(v) the final decision on these questions lies with the Judicial Committee of the Privy Council exercising its devolution jurisdiction whether on preliminary reference from a superior court (including the House of Lords), ${ }^{29}$ on appeal from a superior court (including from the High Court of Justiciary in Edinburgh) ${ }^{30}$ or on a direct reference to the Privy Council made by order of a law officer in proceedings in which he or she is a party. ${ }^{31}$

\section{No time limits for Convention rights challenges under the Scotland}

Act

Section 7(5)(a) HRA imposes a long-stop one year time limit from the date of the act or omission complained of within which court proceedings under that Act alleging breach of Convention rights must be brought. This is, however, subject to any rule imposing a stricter time in relation to the procedure in question, which means that a claim under section 7(1)(a) HRA pursued by way of judicial review in England and Wales will be subject to the three month time limit normally applicable to judicial review applications in that jurisdiction. ${ }^{32}$ By contrast the question of the time within which an action raising a Convention rights challenge as a devolution issue is left unspecified in the Scotland Act. But there are no time limits applicable to judicial review procedure in Scotland - this matter being left to the discretion

${ }^{24}$ H.M. Advocate v R 2003 SC (PC) 21 per Lord Hope at 39D-40A, and per Lord Rodger of Earlsferry at 59D-F, 73C.

25 See paras.5, 16 and 26 of Sch.6 to the Scotland Act 1998. In terms of the detailed Scottish procedural rules on intimation see Chap.25A of the Rules of the Court of Session 1994 and chap.40 of the Criminal Procedure Rules 1996.

26 Scotland Act 1998 s.102(2)(a).

27 Scotland Act 1998 s.102(2)(b).

28 See paras.7-9, 18-21 and 28-29 of Sch.6 to the Scotland Act 1998.

29 See paras.10-11, 22, 30, and 32 of Sch.6 to the Scotland Act 1998.

30 See paras.12-13, 23, and 31 of Sch.6 to the Scotland Act 1998.

31 See paras.33-35 of Schedule 6 to the Scotland Act 1998.

32 Lester \& Pannick, Human Rights Law and Practice, para.2.7.5, n.4. The rule is CPR 54.5(1). 
of the court under the existing common law principles of mora $^{33}$ - and there is no Scottish authority in which a petition for judicial review has been refused on the ground of delay alone, in the absence of evidence of acquiescence by the pursuer or prejudicial reliance on this delay on the part of the defender. ${ }^{34}$ This therefore leaves the acts of the Scottish administration and legislature potentially open to challenge for an indefinite period..$^{35}$

\section{Vires and the Scottish Administration}

As we have noted, the effect of Sections 53 SA and 54 SA (as read in the light of Section 29(2)(d) SA) and of Section 57(2) SA is that "members of the Scottish Executive" (defined, in Section 44(1) SA, as the First Minister, the Law Officers and those other Scottish Ministers who are within the Cabinet) have no power to act in a manner incompatible with any of the Convention rights or with Community law. Consistently with this, paragraphs 1(c), 1(d) and 1(e) of Schedule 6 to the Scotland defines a "devolution issue" as including:

“(c) a question whether a purported or proposed exercise of a function by a member of the Scottish Executive is, or would be, within devolved competence,

(d) a question whether a purported or proposed exercise of a function by a member of the Scottish Executive is, or would be, incompatible with any of the Convention rights or with Community law,

33 See, e.g. King v East Ayrshire Council, 1998 SC 182, IH per Lord President (Rodger) at 196: "It is recognised that the public interest in good administration requires that public authorities and third parties should not be kept in suspense as to the legal validity of a decision for any longer than is necessary in fairness to the person affected by it." See, too, Swan v Secretary of State for Scotland, 1998 SC 479 , IH.

34 See, for example: Singh v Secretary of State for Scotland 2000 SLT 533, OH per Lord Nimmo Smith at 536 para.(8) and Uprichard v Fife Council 2000 SCLR 949 per Lord Bonomy at para.(16). In $R$ (Burkett) v Hammersmith LBC [2002] 1 WLR 1593, Lord Hope of Craighead summarised the Scottish position thus at paras.63-64: "The principal protection against undue delay in applying for judicial review in Scotland is not to be found ... in any statutory provision but in the common law concepts of delay, acquiescence and personal bar: see Clyde \& Edwards, Judicial Review, para.13.20. The important point to note for present purposes is that there is no Scottish authority which supports the proposition that mere delay ... will do. It has never been held that mere delay is sufficient to bar proceedings for judicial review in the absence of circumstances pointing to acquiescence or prejudice ... none of the cases in Scotland provide support for a plea of unreasonable delay, separate and distinct from a plea of mora, taciturnity and acquiescence, in answer to an application for judicial review."

35 See Lord Hope of Craighead House of Lords Hansard 17 Jun 1998: Column 1638: "One has only to look at the devolution issues listed in paragraph 1 of Schedule 6 to see the scope which will exist for challenges to be made. No time limit is set for the making of those challenges. As has been pointed out by several noble Lords, there is to be no revising chamber. So in theory at least - I stress the word theory subject to the exercise of the powers given to the court in Section 93 to vary retrospective decisions, legislation by the Scottish parliament could be set aside as not being within that parliament's competence long after it had been put into effect." 
(e) a question whether a failure to act by a member of the Scottish Executive is incompatible with any of the Convention rights or with Community law."

The question which then arises is whether or not the Scotland Act's definition of "devolution issue" (and consequently the Sections 53-54 SA and 57(2) SA vires limitation on Convention incompatible action) applies equally to Junior Scottish Ministers appointed by the First Ministers under Section 49 SA but who are not in the Scottish Cabinet, or to the Scottish Ministers' civil servants appointed under Section 51 SA, or to those defined under Section 126(7) SA as the holders of non-ministerial offices within the "Scottish Administration" (such as the Registrar of Births, Deaths and Marriages for Scotland ${ }^{36}$ and Procurators Fiscal ${ }^{37}$ who prosecute crimes under the direction of the Lord Advocate).

The answer to this question must be "yes" since any other conclusion would result in the constitutional anomaly that the powers of those employed or holding junior or non ministerial office within the Scottish administration would, in principle, exceed those of the Scottish Ministers who appointed them and to whom they are answerable. For example, if the actions of Scottish officials and junior ministers were not subject to the vires limitations imposed by Section 57(2) SA, then any Convention incompatible action by them would only be prima facie unlawful under Section 6(1) HRA (subject to the Section 6(2) HRA defence), and the courts would have a discretion under Section 8 HRA whether or not to grant a remedy for breach of Convention rights by the Scottish civil servant or junior minister, but would have no such discretion as regards the act of Scottish Ministers holding Cabinet rank. In any event, the general constitutional principle applicable to civil servants is the "Carltona ${ }^{38}$ doctrine", which is that acts done by officials in the exercise of Ministerial functions are to be treated as the Minister's own acts regardless of whether these acts are done personally by the Minister himself or by a junior minister or by departmental officials. The Carltona doctrine does not involve any question of agency or delegation but rather the idea of the official as alter ego of the Minister: the official's decision is constitutionally seen to be the Minister's decision. ${ }^{39}$

Further, if the acts of non-ministerial office holders and members of staff of the Scottish Administration are to be regarded as distinct from the acts of the

36 S.126(8)(a) SA.

37 See Reg.2 of the Scottish Administration (Offices) Order 1999 (SI 1999 No. 1127) which provides: "As from the [20 May 1999] date when section 44(1)(c) of the [Scotland] Act comes into force, the following offices are specified for the purposes of section 126(8)(b) of the Act (offices in the Scottish Administration which are not ministerial offices), namely the offices of procurator fiscal and procurator fiscal depute to which appointments may be made under sections 1(2) and 2 respectively of the Sheriff Courts and Legal Officers (Scotland) Act 1927."

38 See Carltona Ltd v Commissioners of Works [1943] 2 All ER 560.

39 See Metropolitan Borough and Town Clerk of Lewisham v Roberts [1949] 2 KB 608, 629 per Jenkins J; $R$ v Skinner [1969] 2 QB 700, 707F-G, 709A-B per Widgery LJ; In re Golden Chemical Products Ltd [1976] 1 Ch 300, 307C-D per Brightman J; Air 2000 v Secretary of State for Transport (No. 2) 1990 SLT 335; $R$ (National Association of Health Stores) v Department of Health [2005] EWCA Civ 154, paras.23-24 per Sedley LJ, 71 per Keene LJ. 
Scottish Ministers for the purposes of Section 57(2) SA and paragraph 1(d) of Schedule 6 SA, then the Judicial Committee of the Privy Council has wholly misunderstood the nature and extent of its devolution jurisdiction. Every case - bar one - which has come before the Privy Council to 2006 under the devolution statutes has concerned the actions of procurators fiscal and advocates deputes acting as public prosecutors in criminal trials in Scotland, rather than any personal acts of the Scottish Ministers. ${ }^{40}$ In the exercise of its devolution jurisdiction, the Privy Council has become less a

40 The fourteen substantive criminal appeal decisions are, in chronological order: Montgomery v H.M. Advocate, 2001 SC (PC) 1 - decision of Lord Slynn, Lord Nicholls of Birkenhead, Lord Hoffmann, Lord Clyde, Lord Hope of Craighead, 19 October 2000 (Art.6 ECHR and pre-trial publicity); Brown v Stott (Procurator Fiscal, Dunfermline), 2001 SC (PC) 43 - decision of Lord Bingham of Cornhill, Lord Clyde, Lord Hope of Craighead, Lord Kirkwood and Lord Steyn, 5 December 2000 (Article 6 ECHR and the privilege against self-incrimination); McIntosh v HM Advocate, 2001 SC (PC) 89 - decision of Lord Bingham of Cornhill, Lord Hoffmann, Lord Hope of Craighead, Lord Clyde and Lord Hutton, 5 February 2001 (Article 6 ECHR, drug confiscation orders and the presumption of innocence); McLean and another v Buchanan (Procurator Fiscal, Fort William) and another, 2002 SC (PC) 1 - decision of Lord Nicholls of Birkenhead, Lord Hope of Craighead, Lord Clyde, Lord Hobhouse of Woodborough and Lord Millett, 24 May 2001 (Art.6 ECHR, legal aid and the equality of arms between prosecutors and criminal defence lawyers). Millar v Dickson, 2002 SC (PC) 30 decision of Lord Bingham of Cornhill, Lord Nicholls of Birkenhead, Lord Hope of Craighead, Lord Clyde, Lord Scott of Foscote, 24 July 2001 (Article 6 ECHR and possible waiver of the right to an independent and impartial tribunal) Dyer v Watson and Another and HM Advocate v K, 2002 SC (PC) 89 - decision of Lord Bingham of Cornhill, Lord Hope of Craighead, Lord Hutton, Lord Millett and Lord Rodger of Earlsferry, 29 January 2002 (Art.6 ECHR and the factors indicating unreasonable delay). Mills v HM Advocate (No. 2) 2003 SC (PC) 1 decision of Lord Nicholls of Birkenhead, Lord Steyn, Lord Hope of Craighead, Lord Scott of Foscote, Lord Mackay of Clashfern, 22 July 2002 (Art.6 ECHR unreasonable delay between conviction and hearing of appeal and the remedy of a reduction in sentence). R. v H.M Advocate, 2003 SC (PC) 21 - decision of Lord Steyn, Lord Hope of Craighead, Lord Clyde, Lord Rodger, Lord Walker of Gestingthorpe, 28 November 2002 (Art.6 ECHR unreasonable delay in bringing charges and remedies under the Scotland Act); Clark v Kelly, 2003 SC (PC) 77 decision of Lord Bingham of Cornhill, Lord Hoffmann, Lord Hope of Craighead, Lord Hutton, and Lord Rodger of Earlsferry, 11 February 2003 (Article 6 ECHR and the independence and impartiality of the District Court). Flynn and others v HM Advocate, 2004 SC (PC) 1 - decision of Lord Bingham of Cornhill, Lord Hope of Craighead, Lord Rodger of Earlsferry, Baroness Hale of Richmond and Lord Carswell, 18 March 2004 (Articles 5 and 6 ECHR tariffs for mandatory lifers). Holland v HM Advocate, 2005 SC (PC) 3, decision of Lord Bingham, Lord Hope of Craighead, Lord Clyde, Lord Rodger, Baroness Hale, Lord Carswell, 11 May 2005 (Art.6(1) fairness and procedure identification of accused by in the dock of the court). Sinclair v HM Advocate, 2005 SC (PC) 28, decision of Lord Bingham, Lord Hope of Craighead, Lord Clyde, Lord Rodger, Baroness Hale, Lord Carswell, 11 May 2005 (Art.6(1) fairness and disclosure to the defence of relevant information in the hands of the Crown). Kearney $\mathrm{v}$ HM Advocate [2006] UKPC D1, decision of Lord Bingham, Lord Hope, Lord Carswell and Lord Brown (whether temporary judges had the requisite independence from the executive to be Art 6(1) compliant). Ruddy \& Ors. v Griffiths [2006] UKPC D2, decision of Lord Bingham, Lord Hope, Lord Rodger, Lord Carswell and Lord Brown (on acquiescence to a non-impartial tribunal). 
general UK constitutional court and more a third tier court of criminal appeal from Scotland. ${ }^{41}$ All of the eighteen cases before the Privy Council's devolution jurisdiction to the beginning of 2006 have come from Scotland, and only one of these cases has been a civil appeal; and even that one case concerned a challenge to the validity of continued detention - under and in terms of the first Act of the Scottish Parliament the Mental Health (Public Safety and Appeals) (Scotland) Act 1999 - of persons detained in the State Hospital for reasons of public safety. ${ }^{42}$

\section{Section 6(2) HRA and the Scottish administration}

More radically yet, whereas under Section 6(2) HRA a public authority might claim that its Convention incompatible acts were not unlawful because they were constrained so to act by one or more provisions of Westminster primary legislation, or were simply giving effect to or enforcing provisions of some Convention incompatible Westminster derived legislation ${ }^{43}$ no such defence has been given to the Scottish Ministers. This means that no provision is made for the possibility of any "lawful" breach of Convention rights by the Scottish devolved authorities. Curiously, however, the Section 6(2) HRA defence is given to the devolved administrations and assemblies in both Wales ${ }^{44}$ and Northern Ireland. ${ }^{45}$ But because the Scottish Ministers and Parliament have no Section 6(2) HRA defence open to them, a declaration by a court made under Section 4 HRA to the effect that a provision of Westminster legislation is incompatible with the requirements of the Convention will have the effect of rendering ultra vires any act or omission of the Scottish Ministers or Parliament which relies upon the Westminster provision in question.

It is noteworthy that Section 57(2) SA refers to limitations on the powers of the Scottish Ministers under reference to both European Community law and Convention rights. One matter that remains to be resolved is what are the Scottish Ministers to do where Community law and Convention right

41 In addition to the twelve substantive criminal appeals, there have been three preliminary hearings before a three judge panel considering applications for special leave to appeal to the Judicial Committee cases after such leave had been refused by the High Court in Scotland: Hoekstra and others v Her Majesty's Advocate (No. 5) 2001 SC (PC) 37 - decision of the screening committee comprising Lord Slynn, Lord Hope and Lord Clyde, 26 October 2000; Follen v H.M. Advocate, 2001 SC (PC) 105 - decision of the screening committee comprising Lord Bingham, Lord Hope and Lord Clyde, 8 March 2001; and Moir v H.M. Advocate, 2005 SC (PC) 1 - decision of the screening committee comprising Lord Bingham, Lord Hope and Rodger, 17 November 2004.

42 A. v The Scottish Ministers, 2002 SC (PC) 63 - decision of Lord Slynn of Hadley, Lord Hope of Craighead, Lord Clyde, Lord Hutton, Lord Scott of Foscote, 24 July 2001 (Art.5(1)(e) ECHR and the detention of persons of unsound mind).

43 In $R$ v Kansal (No. 2) [2002] 2 AC 69, HL Lord Hope observed (at para.88) that, in his view, the s.6(2)(b) HRA exception was not limited to non-discretionary acts and instead could be prayed in aid by a public authority which could point to a provision of, or made under, a primary Westminster statute which authorised the action in question.

44 See s.107(4)(a) of the Government of Wales Act 1998.

45 See ss.71(3)(a) and 71(4)(a) of the Northern Ireland Act 1998. 
conflict. ${ }^{46}$ But the decision not to afford the Scottish Ministers the possibility of a Section 6(2) HRA defence to any challenges made to the Convention compatibility of their actions is one with radical constitutional implications that have perhaps not yet been fully realised. For the decision means that in relation to the assessment of the lawfulness of acts of the Scottish Ministers - Westminster statutes are placed in a position which is normatively subordinate to the requirements of the Convention. Because the Scottish Ministers have no Section 6(2) HRA defence, Convention rights have the same effect against the Scottish Ministers as do directly effective provisions of Community law - both render their acts ultra vires. Thus any Convention incompatible provision of a Westminster statute effectively falls to be "disapplied" as regards the Scottish Ministers, just as any Community law incompatible provision of a Westminster statute is to be disapplied as regards acts of emanations of the UK State. ${ }^{47}$

And it would appear that this failure to allow for any Convention incompatible activity on the part of the Scottish Parliament and Ministers was not a matter of simple oversight. When the Scotland Bill was before the House of Lords a provision was specifically amended in (and now forms Section 57(3) SA) to ensure that the Lord Advocate, when acting in his capacity as head of the system of criminal prosecution and investigation of deaths in Scotland, might be able to claim a Section 6(2) HRA defence. ${ }^{48}$ In

46 See Aidan O'Neill "The constitutional supremacy of Community Law in the United Kingdom after the Human Rights Act" in de Sousa and Heusel (eds.) Enforcing Community law from Francovich to Köbler: twelve years of the State liability principle Volume 37 Academy of European Law, Trier, Germany (ERA, 2004) pp.87-116.

47 See $R$ v Secretary of State for Transport, ex parte Factortame (No. 2) [1991] 1 AC 603.

48 See House of Lords Hansard 28 October 1998 at Columns 2041-2042 per the then Lord Advocate, Lord Hardie: "Amendment No. $145 \mathrm{~F}$ ensures that the Lord Advocate is able to rely on the protection afforded by Clause 6(2) of the Human Rights Bill when he is prosecuting an offence or acting in his capacity as head of the systems of criminal prosecution and investigation of deaths. Clause 6 of the Human Rights Bill provides that it is unlawful for a public authority which would include the Lord Advocate to act in a way that is incompatible with a convention right. Clause 6(2) provides that it is not unlawful if the act of the public authority was because it could not have acted differently as a result of primary legislation or the public authority was acting to give effect to provisions made under primary legislation. This is intended to protect a public authority where a Westminster Act required it to breach a convention right. The amendment ensures that this protection is also afforded to the Lord Advocate where it is alleged that he has breached Clause 53(2) of the Scotland Bill [now Section 57(2) SA] which requires him to act compatibly with the convention rights. This ensures that the Lord Advocate could prosecute an offence contained in a UK Act even if it were in contravention of a convention right. Without the amendment the offence could be prosecuted by the Crown Prosecution Service in England but not by the Lord Advocate. The amendment also allows him to act in his capacity as head of the systems of criminal prosecution and investigation of deaths in Scotland if he is acting as required by a provision of the UK Act. Without the amendment disapplying Clause 53(2) he could not act in this way ... What is being contemplated - I am not sure that I can think of a specific example - is United Kingdom legislation which creates an offence but which itself was contrary to the convention. ... If an offence were created across the United Kingdom under a UK 
the absence of specific Westminster derived authorisation the Lord Advocate would have, like the rest of the Scottish Ministers, no power to "move the court to grant any remedy which would be incompatible with the European Convention on Human Rights". ${ }^{49}$ The fact that no similar amendment was made in respect of the other Scottish Ministers - or for the Lord Advocate when acting other than as head of Scotland's criminal prosecution service suggests it was intended that the Convention based limits imposed on the powers of the Scottish devolved government would be subject to no exception. But since all those who hold office by virtue of their effective appointment by the Scottish Ministers within areas of devolved competence are governed by the vires controls of Section 57(2) SA - rather than by the lawfulness controls of Section $6 \mathrm{HRA}$ - this means that a declaration of incompatibility made under Section 4 HRA has the effect of actually setting specific and particular limits on the power of those Scottish officials. A practical example may illustrate the issues that this constitutional arrangement may give rise to. In Bellinger $\mathrm{v}$ Bellinger the House of Lords made a Section 4 HRA declaration to the effect that Section 11(c) of the Matrimonial Causes Act 1973, which provided that in England and Wales "A marriage . . . shall be void on the following grounds only, that is to say ... that the parties are not respectively male and female ..." was incompatible with the Convention rights articles 8 and 12 because it prevented the law's recognising the marriage entered into between a man and a transsexual female who on birth in 1946 had been correctly classified and registered at birth as male but had subsequently undergone gender reassignment surgery and treatment. For the purposes of domestic law, however, both parties to the marriage were regarded as being men and hence their marriage was not recognised. As Lord Hope noted:

"When Parliament used the words 'male' and 'female' in section 11(c) of the 1973 Act it must be taken to have used those words in the sense which they normally have when they are used to describe a person's sex, even though they are plainly capable of including men and women who happen to be infertile or are past the age of child bearing. I think that section 5(4)(e) of the Marriage (Scotland) Act 1977, which provides there is a legal impediment to a marriage in Scots law where the parties "are of the same sex", has to be read and understood in the same way. I do not see how, on the ordinary methods of interpretation, the words "male" and "female" in section 11(c) of the 1973 Act can be interpreted as including female to male and male to female transsexuals.[. . .]

69. Her problem would be solved if it were possible for a transsexual to marry a person of the same sex, which is indeed

statute it would be appropriate that one of the considerations for the Lord Advocate would be whether he or she wished to prosecute in Scotland for that offence. Just as the Crown Prosecution Service in England could prosecute, it would be invidious if the Lord Advocate were precluded from prosecuting for the statutory offence under the United Kingdom Act simply because it contravened the convention right. At this stage, I am unable to think of specific examples."

49 See Lord Advocate v Scottish Media Newspapers Ltd 2000 SLT 331 per the Lord President (Rodger) at 333B. 
what the European Court of Human Rights has now held should be the position in Goodwin. The court noted in para 100 of its judgment that article 9 of the Charter of Fundamental Rights of the European Union had departed 'no doubt deliberately' from the wording of article 12 of the Convention in removing the reference to 'men and women of marriageable age'. Article 9 of the Charter states simply that 'the right to marry' shall be guaranteed. The note to article 9 says that it neither prohibits nor imposes the granting of the status of marriage to unions between people of the same sex. It appears that the European Court saw that article as opening up the possibility of transsexuals marrying persons of the opposite sex to their post-operative acquired gender, as it rendered arguments about whether they were in fact of the opposite sex irrelevant. By this route, which bypasses the physical problems which are inherent in the notion of a complete sex change, legal recognition can be given to the acquired gender of post-operative transsexuals. But it is quite impossible to hold that section 11(c) of the 1973 Act treats the sex of the parties to a marriage ceremony as irrelevant, as it makes express provision to the contrary. In any event, problems of great complexity would be involved if recognition were to be given to same sex marriages. They must be left to Parliament. I do not think that your Lordships can solve the problem judicially by means of the interpretative obligation in section 3(1) of the 1998 Act.

70. So I too would dismiss the appeal. But I too would make a declaration that section 11(c) of the Matrimonial Causes Act 1973 is incompatible with Mrs Bellinger's right to respect for her private life under article 8 and with her right to marry under article 12 of the European Convention for the Protection of Human Rights and Fundamental Freedoms." ${ }^{50}$

As Lord Hope notes, if Section 11(c)of the Matrimonial Causes Act 1973 is incompatible with the requirements of the Convention, so too is Section 5(4)(e) of the Marriage (Scotland) Act 1977 which, on its face, prevents same sex couples from marrying. But marriage is, of course, a devolved matter and the Registrar General of Birth, Deaths and Marriages in Scotland is defined, by Section 126(8) SA as holding a non-ministerial office within the Scottish Administration. It would therefore appear to be ultra vires the Registrar in Scotland to refuse to issue a marriage licence to a couple on the basis solely that they are of the same sex, since to do so would be to breach their Article 8 and 12 Convention rights. On this analysis, same-sex couples in Scotland need not have waited for the coming into force of the Civil Partnership Act 2004 before they could have legitimised their unions. They had the right to do so since July 1999 when power to regulate marriages was devolved to Scottish Ministers under the Scotland Act, and they retain the right even subsequent to the coming into force of the Civil Partnership Act to seek to a marriage licence. The fact that no such challenge has been made in

50 Bellinger $\mathrm{v}$ Bellinger [2003] 2 AC 467. 
Scotland to date is if anything symptomatic of the lack of a properly developed public law culture in Scotland and the inability of pressure groups to take cases directly before the Scottish courts. ${ }^{51}$

Another example of the unexpectedly radical implications of the absolute duty placed on the Scottish Executive and Administration to act always in accordance with Convention rights arises from the decision of the Grand Chamber of the European Court of Human Rights in Hirst $\mathrm{v}$ United Kingdom $^{52}$ where it was held, by a majority of twelve votes to five held that the legislation in the UK which disenfranchises all individuals sentenced to a prison term after conviction for the duration of the period of their detention contravenes the requirements of the Article 3 Protocol 1 of the European Convention because it is disproportionate in its impact and effect and is not tailored to the circumstances of the conviction of individual prisoners. The opinion of Judge Caflisch, concurring with the majority, has stated that, in order to comply with the requirements of proportionality, any national law purporting to disenfranchise prisoners on conviction must have the following characteristics.

"[It] cannot be a blanket law: it may not, simply, disenfranchise the author of every violation sanctioned by a prison term. It must, in other words, be restricted to major crimes, as rightly pointed out by the Venice Commission in its Code of Good Practice in Electoral Matters (judgment, section 32). It cannot simply be assumed that whoever serves a sentence has breached the social contract.

The legislation in question must provide that disenfranchisement, as a complementary sanction, is a matter to be decided by the judge, not the executive. This element, too, will be found in the Code of Good Practice adopted by the Venice Commission.

Finally - and this may be the essential point for the present case - in those Contracting States where the sentence may comprise a punitive part (retribution and deterrence) and a period of detention based on the risk inherent in the prisoner's release - the disenfranchisement must remain confined to the punitive part and may not be extended to the remainder of the sentence. In the instant case this would indeed seem to be confirmed by the fact that retribution is one of the reasons adduced by the United Kingdom legislator for enacting the legislation discussed here, and certainly a central one. This reason is no longer relevant, therefore, as soon as a person ceases to be detained for punitive purposes."

51 Compare with Minister for Home Affairs v Fourie, 1 December [2005] SACC and Goodridge and Others v Department of Public Health 18 November [2003] MSC where the south African constitutional court and the Massachusetts supreme court, respectively, held the exclusion of same sex couples from the legal regime of marriage unconstitutional because in violation of their fundamental right to equal treatment.

52 App. No.74025/01 Hirst v United Kingdom (No. 2), ECtHR (GC), 6 October 2005. 
It is clear from the Hirst decision that Section 3 of the Representation of the People Act 1983 which provides that "a convicted person during the time that he is detained in a penal institution in pursuance of his sentence or unlawfully at large when he would otherwise be so detained is legally incapable of voting at any parliamentary or local government election" is incompatible with the Convention right to "free elections" protected under both the Human Rights Act and the Scotland Act. It follows from this that the holding of general elections and any by-elections to the Scottish Parliament under that voting system would be incompatible with respect for the Convention rights of those who have been found to be improperly disenfranchised. Accordingly it is would appear that by virtue of Section 57(2) SA the Scottish Ministers and Administration have no power to participate in or do any official act - for example the provision or allocation of funds - in connection with any such elections to the Scottish Parliament until the franchise thereto has been altered so as to be Convention compatible.

Any such alteration in the franchise to the Scottish Parliament would appear to be the responsibility of the Westminster Parliament, however, by virtue of the provisions of Paragraph B3(b) in Part II of Schedule 5 to the Scotland Act which provides that "elections for membership of the House of Commons, the European Parliament, the [Scottish] Parliament, including the subject matter of . . . the Representation of the People Act 1983 and the Representation of the People Act 1985 ... so far as those enactments apply, or may be applied in respect of such membership" are matters reserved to the Westminster Parliament and fall outwith the legislative competence of the Scottish Parliament and Executive. But in the meantime, the limitations on the powers of the Scottish Ministers as set out in the Scotland Act mean that the Scottish Ministers have no power to participate in or administer any legislative scheme - even one duly passed by the Westminster Parliament and approved by the Scottish Parliament by "Sewel motion" 53 - which is incompatible with the requirements of the Convention. ${ }^{54}$

53 The constitutional convention in the UK post-devolution is that the Westminster Parliament will not normally legislate with regard to devolved matters in Scotland without the consent of the Scottish Parliament. A "Sewel motion" is a motion passed by the Scottish Parliament, in which it consents to the Parliament of the United Kingdom passing legislation on a topic which falls within the devolved legislative competence of the Scottish Parliament.

54 Thus, for example, a challenge may be taken as to the lawfulness of any legislative provision which purports to allow the Scottish Ministers to act in any agency capacity in Convention incompatible elections. See the Scotland Act 1998 (Agency Arrangements) (Specification) Order 1999 (SI 1999 No. 1512) which by art.2(1) purports to specify the functions of a Minister of the Crown which may be exercised by the Scottish Ministers on his behalf under and in terms of s.93(1) SA. These functions include:

- Ss.18(5), 29(4A), 29(5), 29(6) and 29(7) of the Representation of the People Act 1983 (functions relating to funding arrangements for, and the conduct of, parliamentary elections).

- Ss.29(4A), 29(5), 29(6) and 29(7) of the Representation of the People Act 1983 as applied by regulation 3(1) of, and Sch.1 to, the European Parliamentary Elections Regulations 1999 (functions relating to funding arrangements for elections to the European Parliament). 


\section{Northern Ireland Legal Quarterly [Vol. 57, No. 1]}

\section{Conclusion on the Scottish devolutionary settlement}

Although the same substantive Convention rights (those set out in Schedule 1 to the Human Rights Act 1998) have been incorporated throughout the legal jurisdictions of the United Kingdom, those Convention rights have been given a completely different constitutional status in Scotland from the rest of the United Kingdom. Under the Scotland Act 1998, the rights guaranteed under the Convention have, in effect, the status of a higher law as against all and any legislation whether passed by the Westminster Parliament or passed by the Scottish Parliament as well as over any act or omission of a member of the Scottish Executive. ${ }^{55}$ Scotland's new constitution under the Scotland Act mandates this new form of "democratic constitution" previously unknown within the context of the United Kingdom, one in which the judges are supreme in the sense that they have the power to strike down as invalid both:

(i) legislation which has been duly passed by the Scottish Parliament and

(ii) acts of the Scottish Ministers, even where these which might otherwise be warranted or authorized under primary Westminster legislation.

- Ss.29(4A), 29(5), 29(6) and 29(7) of the Representation of the People Act 1983 as applied by art.18 of the Scottish Parliament (Elections etc.). Order 1999 (functions relating to funding arrangements for elections to the Scottish Parliament).

- S.47(1) of the Representation of the People Act 1983 (function relating to determining terms and conditions for loans of equipment for local government elections).

- Regs.43(2) and 55(2) of the Representation of the People (Scotland) Regulations 1986 (functions of directing an adaptation of the electors lists and electoral register in force inconsequence of an alteration of parliamentary polling districts). - Reg.51(2) of the Representation of the People (Scotland) Regulations.1986 (function of receiving copies of electoral register).

- Art.20(1) of the Scottish Parliament (Elections etc.) Order 1999 (function relating to determining terms and conditions for loans of equipment for Scottish parliamentary elections).

- Art.23(1) of the Scottish Parliament (Elections etc.) Order 1999 (function relating to the giving of directions to the discharge of registration duties). - Arts.39(4), 40(3)(a), 40(5), 47(1), 47(6), 49(2) and 49(3)(b) of the Scottish Parliament (Elections etc.) Order 1999 (functions relating to the receipt of various returns and declarations in relation to election expenses).

- Art.55(2) and (3) of the Scottish Parliament (Elections etc.) Order 1999 (functions relating to the publication of notice of time and place of inspection of returns and declarations in relation to election expenses).

- Art.57(1) and (4) of the Scottish Parliament (Elections etc.) Order 1999 (functions relating to the making available for inspection various returns and declarations in relation to election expenses). Para.20(4) of Sch.4 to the Scottish Parliament (Elections etc.) Order 1999 (function in relation to the receipt of returns relating to postal ballot papers). Para.1(2) of Sch.7 to the Scottish Parliament (Elections etc.) Order 1999 (function in relation to the determination of questions about the use of rooms in school premises for election meetings).

55 See Aidan O'Neill: "Fundamental Rights and the Constitutional Supremacy of Community Law in the United Kingdom after Devolution and the Human Rights Act” (2002) Public Law 724-742. 
In French constitutional writing, the idea of the judiciary having such absolute power to review and strike down provisions of laws which have been duly passed by the legislature has been termed "un gouvernment des juges". ${ }^{56}$ This is how the French would characterise the American constitutional position under which, since the seminal judgment in 1803 of the Supreme Court of the United States in Marbury v Madison, ${ }^{57}$ the courts of that country have claimed the power to declare "a legislative act contrary to the constitution" as "not law". The US model involving the "Government of Judges" is one which has been imported into the devolved Scottish constitution. As the following survey of human rights decisions made by the courts in Scotland under the devolved constitution shows this is a development which has not been universally welcomed within the Scottish judiciary.

\section{Human Rights Litigation in Post-Devolutionary Scotland}

Given the statistics quoted at the outset of this article regarding the relevance of violent crime in Scotland and the high prisoner population, it should perhaps have come as no surprise that the bulk of human rights litigation to date following upon the devolution of power to the Scottish executive has been in the area of criminal justice, nor that the other main area in which courts have wrestled with Convention rights has been in civil claims brought by prisoners.

One explanation of this is a simple access to justice point. The vast bulk of individuals cannot afford to go to court and litigate against the government. Given the potential liability for the costs and expenses of the other side should one lose, one has either to be very rich - or so poor as to be eligible for legal aid - before one could even contemplate litigation. And litigation against government defenders is all the more fraught because, unlike ordinary litigants, the government recognises no general economic imperative to settle cases taken against it. The government's untrammeled access to tax-payers' pockets is such that it considers that it can afford to insist on litigating to the bitter end - regardless of cost - so that every avenue of appeal must be exhausted before it accepts defeat. This is a daunting prospect for all but the most determined litigants. And the most determined litigants are to be found amongst those who are seeking to avoid the loss of their liberty consequent upon their conviction and sentencing for a criminal offence and among those who, having lost their liberty on conviction, now have time enough on their hands to test the lawfulness of the actions of those by whom they are detained.

Further, the restrictive rules on standing (or "title and interest to sue") in Scotland as compared to the rules in England mean that there is no real scope for public interest litigation by pressure groups or non-government organizations. ${ }^{58}$ And the Scottish courts have been traditionally unwilling to allow themselves to be used as debating fora for the resolution of purely

56 Davis "A Government of Judges: an historical review" (1987) 55 American Journal of Comparative Law 559.

57 Marbury v Madison (5 US 368, 389, (1803) 1 Cranch 103 at 177.

58 See Aidan O'Neill "Judging Democracy: the devolutionary settlement and the Scottish constitution” (2004) 8 Edinburgh Law Review 177-205. 
academic disputes and have been hostile to the idea that they might be asked to pronounce "bare declarators" of law. Instead cases can only be brought in Scotland by individuals who can say that their rights are being breached and that they have a true on-going and live interest to have that matter resolved by the court. ${ }^{59}$

All of these factors have, by a process of elimination, left human rights issues against the Scottish Ministers to be litigated within the context of criminal prosecutions and, in the civil sphere, by convicted prisoners complaining of aspects of their detention. This has given a rather lop-sided feel to human rights in Scotland. From the decided cases, at least, human rights appears to be concerned only with asserting the rights of prisoners and criminals and the duty of courts to vindicate those rights and provide compensation for their violation. This has not been a development which has been universally welcomed, whether in the populace at large, the popular press, the politicians in charge of our affairs, or indeed among a number of the judges faced with these new claims before them. A feeling of injustice may also have been engendered by the fact that Convention rights challenge to the criminalisation of previously lawful activity (for example foxhunting ${ }^{60}$ ) have failed whereas Convention rights cases brought by convicted prisoners have been successful. Prisoners are seen as undeserving and so their grievances should not be allowed to clutter up the courts and impede the speedy hearing and resolution of the legal claims of decent ordinary citizens. As Lord Hardie observed in Davidson v Scottish Ministers (No. 1):

"[T] of a campaign involving other prisoners, to obtain what was, in effect, an advisory opinion of the court. Had the reclaimer pursued his remedies under the Prison Rules, the present application might have proved quite unnecessary . . . [C]ounsel for the reclaimer acknowledged that the reclaiming motion was intended to deal with abstract questions of principle. I strongly disapprove of the procedure adopted by the reclaimer and his legal advisers in this case. It is a matter for future consideration whether the court should dismiss at the earliest opportunity any similar such petitions unless the petitioner has had recourse to and exhausted his remedies under the Prison Rules. If the court does not adopt such a stance there is a real risk that, by reason of the priority given to petitions for judicial review, judicial time and public funds will be utilised unfairly at the expense of other litigants." ${ }^{61}$

The underlying complaint appears to be that the litigation that was before the court - under which the prisoner challenged the compatibility of the conditions in which he was detained on remand in HMP Barlinnie with the

59 See Adams v Advocate General, 2003 SC 171, OH for a discussion of the requirements of title and interest in the context of a challenge to the Convention compatibility of the restrictions on fox hunting contained in the Protection of Wild Mammals (Scotland) Act 2002.

60 See Adams v Scottish Ministers, 2004 SC 665, IH and Friend v Lord Advocate [2005] CSIH 69.

61 Davidson v Scottish Ministers (No.1), 2002 SC 205 per Lord Hardie at 216-217. 
Article 3 ECHR prohibition on inhuman and degrading treatment and sought an order from the court removing him from these condition - was the continuation of politics by other means and was therefore illicit, as an improper use of court time and resources. The prisoner's application was accordingly summarily rejected. Ironically, however, the refusal on the part of this court to consider making such an order was itself subsequently overturned on the grounds that Lord Hardie as one of the bench hearing the application had failed to disclose his own prior political involvement as Lord Advocate on the very question of law - the competency of pronouncing coercive orders against the Scottish Ministers - then at issue before them. ${ }^{62}$

In Napier $\mathrm{v}$ The Scottish Ministers, ${ }^{63}$ the prisoner litigant similarly complained that the cell in which he was detained on remand was Article 3 ECHR incompatible because: it was grossly inadequate in terms of living space, lighting and ventilation; the sanitary arrangements involved using a chamber pot in the presence of his cell-mate and subsequently "slopping out" the contents; and the extent to which he was confined in his cell was excessive with the periods of exercise and recreation outside the cell wholly inadequate. Unlike Mr. Davidson, he was successful in persuading the judge at first instance that he had made out a prima facie case which was strong enough for the judge to order his immediate transfer from his conditions of detention within HMP Barlinnie Prison to a conditions which complied with Article 3 ECHR The case subsequently went to a six week proof and - after consideration of expert evidence and Reports from the European Committee for the Prevention of Torture (CPT) - the Lord Ordinary, Lord Bonomy held that the combination of the "triple vices" of cellular and prison hall overcrowding, slopping out and impoverished regime in C Hall of Barlinnie Prison, Glasgow were such as to be capable of constituting in Scotland in 2001 a breach of Article 3. As he noted:

"[T]o detain a person along with another prisoner in a cramped, stuffy and gloomy cell which is inadequate for the occupation of two people, to confine them there for at least 20 hours on average per day, to deny him overnight access to a toilet throughout the week and for extended periods at the weekend and thus to expose him to both elements of the slopping out process, to provide no structured activity other

62 Davidson v Scottish Ministers (No.2), 2005 SC (HL) 7. This decision to find that Lord Hardie's participation in the case breached the necessary appearance of judicial impartiality was criticised by Louis Blom Cooper in "Bias on appeal" (2005) Public Law 225 at 228 in the following terms: "Whether or not the present law of bias is sustainable to test the impartiality of the trial judge, the executive and legislative roles performed by Lord Hardie when he was Lord Advocate cannot properly constitute a frame of mind (even assuming that Lord Hardie fully recalled his role in advising as a member of the Government on s.21 of the Crown Proceedings Act 1947 which apparently he did not) that would exercise in the courtroom bystander a proper feeling of bias. If one assumes (as one must) that an 'open mind' is not an empty mind and that Lord Hardie's politico-legal past included, even demonstrably, a relevance to the point of law raised by Mr. Davidson, an acknowledgement of the judicial role would preclude anything that called for disqualification or dismissal, at least not automatic."

63 Napier v The Scottish Ministers [2002] UKHRR 308; [2001] 1 Prison Law Reports 347 per Lord Macfadyen at para.17. 
than daily walking exercise for one hour and one period of recreation lasting an hour and a half in a week, and to confine him to a 'dog box' for two hours or so each time he entered of left the prison was, in Scotland in 2001, capable of attaining the minimum level of severity necessary to constitute degrading treatment and thus to infringe Article 3."64

The impact of these conditions, when taken together, were found by the judge to have diminished the petitioner's human dignity and to aroused in him feelings of anxiety, anguish, inferiority and humiliation. The Lord Ordinary also found that Article 8 ECHR was breached in the circumstances of the case. The detention of the petitioner in the conditions displaying the "triple vices" was held not to be "necessary in a democratic society". Interestingly, in reaching his decision on that point, Lord Bonomy took into account various statements made before the Scottish Parliament by members of the Executive, notably the then Minister of Justice, Jim Wallace MSP. From these statements, Lord Bonomy was able to judge that positive choices had been made by the Scottish Executive in the knowledge that there was an urgent need to address prison conditions. He noted in his judgment that in 1994 the conditions in HMP Barlinnie were criticised by the Committee for the Prevention of Torture. He also heard evidence that slopping out had generally been abolished in prisons in England and Wales by April 1996. The judge found from the Scottish Parliamentary material put before him by the petitioner's representatives that the Scottish Ministers could easily have installed integral sanitation in the cells in C Hall before 2001. Funds were available to them for this purpose but these had been allocated elsewhere. The Scottish Ministers were also found to have breached their common law duty to take reasonable care for the petitioner's health and safety in that the stress on the petitioner consequent upon the conditions of his detention was found to have contributed to the resurgence and exacerbation of his preexisting eczema. In the circumstances an award of $£ 2,000$ plus interest was made to the petitioner to reflect the loss, injury and damages sustained by him in the course of the 42 days in which he was detained in the conditions in question.

The decision of Lord Bonomy was unsuccessfully appealed against by the Scottish Ministers to the Inner House, ultimately only on the question of the appropriate standard of proof to be applied by domestic courts in Article 3 ECHR cases. The First Division held that:

"in civil proceedings in Scotland in which a finding is sought from the court that there has been an act or a failure to act by a public authority which is incompatible with the requirements of Article 3 of the European Convention on Human Rights, the appropriate standard of proof is the ordinary standard of proof applicable to civil cases in Scotland, namely, proof on a balance of probabilities." 65

The Scottish Ministers declined to exercise their further right of appeal to the House of Lords.

64 Napier v Scottish Ministers, 2005 SC 229, OH at para.75.

65 Napier v Scottish Ministers, 2005 SC 307, IH. 
Lord Bonomy's judgment has since been publicly criticised by a retired Scottish judge (and former Solicitor General for Scotland) for its political nature and impact. Lord McCluskey wrote in a newspaper article as follows:

"[T]he most remarkable feature of the Napier case was that the court accepted evidence that the Executive had deliberately decided to spend its limited financial resources on other things, in the light of their judgment as to what the public interest required. . . .

The decision as how limited public (i.e. taxpayers') funds are to be spent within the criminal system is a matter for elected politicians not for judges. How can it be for judges to decide that spending money on improving toilet facilities for convicted criminals is more important than spending that money on tackling domestic violence or on trying to fight the menace of dangerous drugs?"66

Lord McCluskey had while still serving as a judge in Scotland previously expressed - in fairly robust terms - a certain scepticism as to the use to which the human rights legislation might be put; describing the incorporation of the Convention rights into domestic law as "a field day for crackpots, a pain in the neck for judges and legislators, and a goldmine for lawyers". ${ }^{67}$ The tone and content of these remarks were subsequently found by the High Court of Justiciary to give rise to a legitimate apprehension that Lord McCluskey could not then be seen to apply questions arising out of that particular branch of the law with the necessary appearance of judicial impartiality ${ }^{68}$ It may be that the decision in Napier provided for him the confirmation of his earlier trenchantly expressed views on the unwisdom of incorporating the Convention.

This publicly expressed judicial hostility to human rights litigation for prisoners' rights appears to rest on the unspoken idea that justice is a limited commodity, or a zero-sum game such that for justice to be done to one means that an injustice is perpetrated against another. While there is no doubt that the claims of the victim to a form of restorative (and indeed individually retributive) justice are under-acknowledged within our present criminal and civil justice system it is not clear why that should constitute a basis for the demand that prisoners be excluded from any further participation in the justice system, or be denied the opportunity to air their grievances and seek vindication of their rights before the courts. It is clear that the individuals most directly aware of the activities of the particular prison administration are the imprisoned.

Another possible response to criticism of this kind of litigation might be to note that in improving the position of prisoners vis à vis the State one may improve the position of everyone, so that it is not just the undeserving who benefit from prisoners' rights litigation. Thus the abstract matter of principle that was before the Extra Division in Davidson (and to which Lord Hardie took exception) was the question as to whether or not it was ever open to the

${ }^{66}$ Lord McCluskey "Opinion” in The Scotsman 3 August 2005.

67 Lord McCluskey "Verdict" in Scotland on Sunday 6 February 2000

68 See Hoekstra v H.M. Advocate (No. 2) 2000 JC 391. 
court to pronounce interdict or an order for specific performance against officers of the Crown (such as the Scottish Ministers) to compel them to comply with the law. Surely the establishing of such a principle can be seen to be potentially of use to all litigants faced with an abuse or excess of State power? In the event, when the decision of the Extra Division in Davidson was eventually appealed by the (former) prisoner petitioner to the House of Lords, the appeal was allowed unanimously, with Lord Hope observing as follows:

“36. In McDonald v Secretary of State for Scotland 1994 SC 234, 238-239, Lord Justice Clerk Ross said:

'It is thus clear that certain restrictions are imposed by section 21 [of the Crown Proceedings Act 1947] upon the granting of interdict in any civil proceedings against the Crown. The Act of 1947 in this respect changed the law of Scotland. Prior to the passing of the Act of 1947, the court in Scotland did on occasion pronounce interdict and interim interdict against the Crown (Russell v Magistrates of Hamilton (1897) 25 R 350; Bell v Secretary of State for Scotland 1933 SLT 519). . . . I accordingly agree with counsel [for the Secretary of State, the Lord Advocate, Lord Rodger of Earlsferry] that one effect of the Crown Proceedings Act 1947 has been to deprive litigants in Scotland of a right which they previously had, namely, a right to obtain interdict and interim interdict against the Crown.'

37. Support for this view was undoubtedly to be found in the fine print of the Act. No one can pretend that it is easy to follow. It is obvious at a glance that the draftsman failed to examine the implications for the Scottish system to the same level of detail as is to be found in the provisions that are applicable in England. But those who cared for the structure and orderly development of the law found it hard to believe that this was indeed what Parliament had intended. Why should litigants in Scotland have been deprived in 1947 of a remedy which they had previously enjoyed and was, for the first time, being made available to their counterparts in England? Surely there would have been a protest about this result, if anyone had thought to explain that this was the intention while the Bill was being discussed in Parliament.

38. That having been said, the decision in McDonald has been regarded as having settled the issue in Scotland for over a decade. The appellant's attempt to open it up in the present proceedings, predictably, met with no success when the Extra Division heard the reclaiming motion against the Lord Ordinary's interlocutor. We on the other hand have had the benefit of examining the issue in a tribunal which draws its membership from all parts of the United Kingdom. There are occasions when those of your Lordships who come from Scotland feel justified in defending Scots law and the Scottish legal system against what are perceived to be alien influences. But this is not one of them. There is everything to be gained by the sharing of views among your Lordships which it has been 
possible to enjoy in this case. This has helped greatly, as we step back and try to take a broader view of section 21 of the 1947 Act.

[...]

54. I would summarise the conclusions which I have reached about the meaning of section 21 in its application to Scotland in this way. There are excluded from the expression 'any civil proceedings' in section 21(1) and section 21(2) proceedings by way of judicial review where relief is sought in respect of acts or omissions of the Crown or of an officer of the Crown acting as such. Proviso (a) to section 21(a) extends to any proceedings in which a remedy is sought against the Crown in private law proceedings, but not otherwise." ${ }^{69}$

And in Beggs v Scottish Ministers ${ }^{70}$ the issue that was before the Inner House was whether or not individual civil servants can be called before the court to account for their contempt in failing to ensure that undertakings which had been given to the court on behalf of the Government were respected. Again, surely, the establishment of the principle that civil servants exercising State power may be held directly accountable to the court for their actions or omissions may be thought to be a matter of interest and significance not only to prisoners, but to everyone.

It is readily apparent, however, that there remains among at least a certain sector of the higher judiciary based in Scotland disquiet and unease about the constitutional position in which the Scottish devolutionary settlement has placed them. The fear appears to be that they are being required to enter into and make decisions on matters - such as the proper allocation of budgetary funds - in which they have little expertise and no democratic legitimacy. The problem is that is what the law requires them to do. A radical constitution is foisted on a conservative judiciary - the antisyzygy continues.

\section{The Scottish Human Rights Commissioner}

In March 2000, the Lord Advocate and the then Minister for Justice stated that the Scottish Ministers were considering the establishment of a human rights commission. Following a period of public consultation in 2003 the Scottish Executive announced their intention to put forward a Bill before the Scottish Parliament to establish the office of the Scottish Human Rights Commissioner (SCHR). Subsequent to the Scottish Executive announcing its proposals to create a human rights commission in Scotland, the UK Government announced its intention to create a Commission for Equality and Human Rights (CEHR) for England and Wales and Scotland. This UK proposal was set out in the Equality Bill which was introduced into the Westminster Parliament as a House of Lords Bill on 18 May 2005 and given royal assent as the Equality Act 2006. Some five months after the Equality Bill had been introduced into the Westminster Parliament, on 7 October

69 Davidson v Scottish Ministers (No. 1), [2005] UKHL 74, 2006 SLT 110 (Lord Nicholls of Birkenhead, Lord Hope of Craighead, Lord Rodger of Earlsferry, Lord Carswell, Lord Mance) per Lord Hope at paras.36-38, 54.

70 Beggs v Scottish Ministers, 2005 SC 342, IH. 
2005, the Scottish Commissioner for Human Rights Bill was introduced as an Executive Bill before the Scottish Parliament. The UK and Scottish Executives have apparently independently decided to create their own distinct Human Rights Commissions and Commissioners operating under distinct legislative frameworks.

But the whole question of the possible inter-relationship between the CEHR set up by Westminster and the SCHR to be established by the Scottish Ministers and Parliament seems to have been barely thought through. One of the complexities of the current Scottish constitutional arrangements is the fact that the Human Rights Act and the Scotland Act were drafted by wholly distinct Whitehall departments and little effort was made to co-ordinate the two Bills in their passage through the Westminster Parliament. This problem of complexity in constitutional structures for the protection of human rights in Scotland has now been compounded by the fact that there is little or no evidence of thought out co-ordination between the Westminster proposal for a British Commission for Equality and Human Rights and the Holyrood proposal for a Scottish Commissioner for Human Rights.

The very least it might be expected that each Commission(er) should have similar remits and investigative and coercive powers as well as similar powers to pursue and intervene in court actions. But that is not to be. The proposed Scottish Commissioner for Human Rights will have far less powers than the British Commission for Equality and Human Rights. Thus, while the CEHR is to be given statutory "title and interest" to raise actions and applications for judicial review before the courts in Scotland in any proceedings relevant to its functions (including human rights issues in reserved matters), the SCHR will be given no power either to raise actions in its own name before the courts in the public interest or to assist others who claim to be the victims of the violation of their rights in bringing human rights cases. The SCHR is given a limited power of intervention in civil cases before the Scottish courts but it will have no power to intervene in criminal cases. And the SCHR will have no power to investigate individual complaints of human rights abuses and any recommendations made in inquiries into the policies and practices of public authorities in Scotland will not be legally binding on any party. The CEHR's powers to conduct inquiries are broader than the Scottish Commissioner's in that the CEHR will be able to conduct enquiries into any matter relating to its human rights duties and its inquiries are not restricted to particular types of organisations. Further, in contrast to the CEHR which may give financial assistance to human rights NGOs, the SCHR will not have any grant-giving powers. As has been noted:

"Given the fact that the [Scottish] Commissioner will not have the power to support individual cases, limited access to justice generally for individuals, and an NGO sector without the resources to fund cases, there is no guarantee that the strategically important cases in which the Commission might helpfully intervene will be litigated. This will severely restrict the ability of the Commissioner to operate at a proactive strategic level, and will sit in stark contrast to the position of the CEHR in England and Wales, and in Scotland on reserved issues. . . . The Northern Ireland model with an Equality Commission and a HRC with powers to give assistance to 
individuals, and to bring proceedings in its own name, as well as monitoring the law and conducting investigations, serves as a model to which the EOC considers that all nations of the United Kingdom, including Scotland, should aspire. While the creation of the post of Scottish Commissioner for Human Rights is a welcome move, the EOC considers that the role and remit do not go nearly far enough to ensure the creation of a human rights culture in Scotland."

There is clearly an overlap both in terms of function, responsibilities and jurisdiction between the CEHR and the SCHR which is apparently to be addressed and alleviated by the conclusion of a Memorandum of Understanding between the two bodies on how they will co-operate on matters of mutual interest. It is apparently envisaged that whereas the CEHR will have a general overall remit for human rights matters in England and Wales, the CEHR's human rights role in Scotland will be restricted to reserved human rights issues and be a matter for Westminster: thus, such issues as data protection, elections, immigration and asylum, national security, competition, consumer protection, transport, social security, employment, discrimination and equal opportunities and broadcasting being all reserved issues might properly fall within the British Commission's Scottish remit. The SCHR's focus will, by contrast, be on devolved human rights issues which fall within the jurisdiction of Holyrood and will have regard not simply to the European Convention on Human Rights but all other international human rights instruments which the UK has ratified, although not specifically incorporated into domestic law. ${ }^{72}$ It is envisaged in the Equality Act 2006 that the CEHR might take action in respect of devolved issues if the Scottish Commissioner gives consent to the CEHR to do so, but this apparent power of veto over the power of the CEHR in Scotland is not reflected in the terms of the Scottish draft legislation which sets up the SCHR.

The potential for confusion, duplication and for boundary disputes between the two bodies is clear. In addition the two new bodies will have to work with and co-ordinate their activities with the existing Scotland's Commissioner for Children and Young People, established by the Commissioner for Children and Young People (Scotland) Act 2003 and tasked with promoting and safeguarding the rights of children and young people." In the event, it is to be hoped that the creation of a multiplicity of

71 See Muriel Robison Written Submission to the Justice I Committee of the Scottish Parliament on behalf of the Equal Opportunities Commission on the Scottish Commissioner for Human Rights Bill 18 November 2005 (available online at http://www.scottish.parliament.uk/business/committees/justice1/inquiries/hrb/j105 -hrb-evid-00.htm).

72 Given that it is clear that under and in terms of s.58 SA and para.7(2)(a) in Part I of Sch.5 SA all of the UK's international obligations bind the Scottish Ministers as a matter of domestic law, then it may be argued that the Scottish constitution created under the Scotland Act is now a monist one for the purposes of international law, rather than the dualism which still characterises the UK constitution. Whether the international obligations which bind the Scottish Ministers as a matter of domestic law can be prayed in aid before the court by private litigants is more problematic however: see Friend v Lord Advocate [2005] CSIH 69. 
distinct (and potentially competing) human rights Commissions and Commissioners holding a remit over human rights matters in Scotland will not be to the detriment of overall human rights protection within Scotland.

\section{Conclusion}

The devolutionary settlement in Scotland is an on-going constitutional experiment. The six years of its operation to date have revealed certain tensions, focusing most particularly around the question of the proper role of judges within a democratic polity. The United States has had two hundred years of experience with a constitution interpreted as mandating judicial supremacy, and there clearly remain tensions in its operation. The consequent juridicalisation of politics in that country has resulted in a perception of the politicisation of the judiciary, particularly in the members of the US Supreme Court ${ }^{73}$ But the idea of judges as open political players runs wholly counter to the basic constitutional traditions of the United Kingdom where the preservation of the appearance of judicial impartiality is seen as being of fundamental importance. ${ }^{74}$

If the appearance of judicial impartiality is in danger of being compromised by the current constitutional position in which judges are placed under the devolutionary settlement, it may be that change is required in the Scottish constitution. Two options for change occur. First, that the Westminster legislature determine that "Convention rights" challenges against the Scottish Ministers should no longer be considered to raise devolution issues, and the Scottish Ministers then be treated on this matter as every other public authority in the United Kingdom, subject to the procedures of the Human Rights Act only. The result of such a change would be that the Privy Council would no longer have jurisdiction to hear criminal appeals from Scotland with the consequence that - in criminal matters at least - Scotland would be able to go its own way in Convention rights matters, untrammeled by UK wide considerations. This was the option recommended by Lord Bonomy in the context of his review into the practice and procedure of the High Court of Justiciary. He stated:

"The only practical reason for ever categorising such issues as devolution issues was to ensure that recognition was given to the Convention rights during the period between the implementation of the Scotland Act and the implementation of the Human Rights Act, but even there it was a rather artificial way of introducing Convention rights to Scottish criminal procedure. That interim period is now over. Schedule 6 of the Scotland Act should be amended to make it clear that acts or failures to act by the Lord Advocate as prosecutor, and anyone acting on his authority or on his behalf as prosecutor, are excluded from the definition of a devolution issue. The Scottish

73 See, e.g. the decision in Bush v Gore 513 US 98 (2000) (00-949) where the US Supreme Court in a five-four split decision ruled on the validity of the Florida count in the 2000 US Presidential election thereby giving the election to George W. Bush notwithstanding his failure to achieve a majority of votes in his favour nationwide.

74 See, for example, In re Pinochet (No. 2) [2000] AC 119. 


\section{Executive should urge the United Kingdom Parliament to make that amendment. ${ }^{75}$}

But such a constitutional change might itself set up new tensions within the Union however, since the High Court of Justiciary has, post-devolution, taken at times a fairly radical approach to the application of Convention rights considerations to criminal procedures. Thus in Brown v Stott ${ }^{76}$ the Scottish criminal appeal court found that the prosecuting authorities could not lead and rely in court on evidence of an admission (regarding the identity of the driver of a car) which the accused was compelled to make to the police under Section 172(2)(a) of the Road Traffic Act 1988 as this was said to contravene her Convention right against self-incrimination. And in $H M$ Advocate $\mathrm{v}$ McIntosh, the Scottish criminal appeal court found that the assumptions set out in Section 3(2) of the Proceeds of Crime (Scotland) Act 1995 relating to the recovery of the proceeds of drug trafficking were incompatible with the presumption of innocence set out in Article 6(2) ECHR. ${ }^{77}$ Both of these decisions were overturned when the cases were taken to the Privy Council on Crown appeals. In coming to the decision in Brown $\mathrm{v}$ Stott Lord Steyn sitting as one of the Board of the Privy Council made the following general observations, implicitly critical of the approach taken by the Scottish court:

"[A] single-minded concentration on the pursuit of fundamental rights of individuals to the exclusion of the interests of the wider public might be subversive of the ideal of tolerant European liberal democracies. The fundamental rights of individuals are of supreme importance but those rights are not unlimited: we live in communities of individuals who also have rights." 78

Similarly, in reversing the decision of the Scottish criminal appeal court in McIntosh $\vee$ HM Advocate, Lord Bingham stated his preference for the approach which had been taken by the Court of Appeal in England and Wales, as he observed:

"The statutory scheme contained in the 1995 Act is one approved by a democratically elected Parliament and should not be at all readily rejected. I would for my part endorse the conclusion of the Court of Appeal (Criminal Division) in $R \mathrm{v}$ Benjafield [2001] 3 WLR 75, 103, para 87:

'It is very much a matter of personal judgment as to whether a proper balance has been struck between the conflicting interests. Into the balance there must be placed the interests of the defendant as against the interests of the public, that those who have offended should not profit from their offending and should not use their criminal conduct to fund further offending. However, in our judgment, if the discretions which are given

75 Improving Practice: the 2002 Review of the Practices and Procedure of the High Court of Justiciary by the Honourable Lord Bonomy at para.17.14. The report is also available on-line at http://www.scotland.go vuk/library5/justice/rppj-00.asp.

76 Brown v Stott, 2000 JC 328.

77 McIntosh v HM Advocate, $2001 \mathrm{JC} 78$.

78 Brown v Stott, 2001 SC (PC) 43 per Lord Steyn at 63. 
to the prosecution and the court are properly exercised, the solution which Parliament has adopted is a reasonable and proportionate response to a substantial public interest, and therefore justifiable." "79

If the Scottish criminal courts were to maintain a different line on the protection, interpretation or remedies available for breach of Convention rights than the courts in the rest of the United Kingdom, then this might then open arguments (whether in applications to the European Court of Human Rights or before the domestic courts) that such difference in treatment may itself be a breach of Article 14 ECHR which provides that "the enjoyment of the rights and freedoms set forth in this Convention shall be secured without discrimination on any ground such as ... race ... national or social origin, birth or other status." ${ }^{80}$ The English have been found, after all, to constitute a distinct racial group from the Scots for the purposes of the Race Relations Act $1976,{ }^{81}$ and the distinctive ethnicity of the Welsh and Irish is not in dispute.

It should be noted that the possibility of such an Article 14 ECHR based discrimination claim already exists even under the existing constitutional arrangements. Currently a failure to bring a criminal prosecution against a person charged with a criminal offence within a reasonable time attracts quite different remedies in Scotland compared to the rest of the United Kingdom as a result of a divergence in approach between the Privy Council and the House of Lords. The Privy Council (in a divided 3:2 devolution jurisdiction decision) has held that such a failure in Scotland constitutes a breach of Article 6(1) ECHR and that the Lord Advocate therefore has no power to institute or maintain a criminal prosecution after a reasonable time has passed; the accused benefits from the delay by being able to avoid any trial. $^{82}$ But a nine judge House of Lords (in a divided 7:2) decision has sought to reject this approach for England and Wales ${ }^{83}$ holding, instead, that

79 McIntosh v HM Advocate, 2001 SC (PC) 89 per Lord Bingham at 102 para.36.

80 See, for example, Dudgeon v United Kingdom (1981) 4 EHRR 149 where a claim for breach of Article 14 ECHR in conjunction with Article 8 ECHR was based on the fact that while homosexual conduct had been decriminalised in Great Britain, it remained illegal in Northern Ireland. In the event, the Court did not find it necessary to deal with the Article 14 discrimination point, having found in favour of the substantive art.8 case - that the continued existence of the Northern Ireland legislation contravened individuals' right to respect for their private life.

81 See BBC Scotland v Souster, 2001 SC 458; [2001] IRLR 150, IH.

82 H.M. Advocate v R 2003 SC (PC) 21, decision of 28 November 2002, Lord Hope of Craighead, Lord Rodger of Earlsferry, and Lord Clyde forming the majority with Lord Steyn and Lord Walker dissenting.

83 S.103 of the Scotland Act 1998, s.82 of the Northern Ireland Act 1998 and para.32 of Sch. 8 to the Government of Wales Act 1999 all assert the binding nature of decisions of the Judicial Committee of the Privy Council in proceedings under these Acts in all other courts and legal proceedings, (apart from later cases brought before the Privy Council). The Government fully intended that this meant that decisions of the Privy Council exercising its devolution jurisdiction should be binding upon the Appellate Committee of the House of Lords. As Lord Sewel advised Parliament (House of Lords Hansard 8 October 1998 per Lord Sewell at Column 619): 
Article 6(1) ECHR gives a right to be tried within a reasonable time but not a right not to be tried after an unreasonable time. Accordingly, it remains lawful for the Crown Prosecution Service in England and Wales to initiate criminal prosecutions after a reasonable time has passed, any unreasonable delay in the proceedings being recognized by the courts only in terms of possible compensation or reduction in sentence rather than as a bar to prosecution. ${ }^{84}$ The consolidation of the devolution jurisdiction of the Privy Council with the appellate jurisdiction of the House of Lords into the new UK Supreme Court - as provided for by Section 40 of (and Schedule 9 to) the Constitutional Reform Act 2005 - may provide a forum in which this divergence in approach may be resolved and in future avoided. But unless and until that court is established, however, there remains something of a constitutional impasse which can only invite further litigation on these issues.

The second option for constitutional change might be to bring an end to the judicial supremacy on which the new Scottish constitution is based and to place the Scottish Parliament and Executive in the same legal position as the UK Parliament and Executive. On this model the judges could no longer simply strike down Scottish legislation but would have the power only to declare it to be Convention incompatible, leaving it to the Scottish legislature to decide whether, how and when to amend the legislation in question in the manner suggested by the judges. But the political implications of any such move might be regarded as too serious. If the Scottish Parliament and Executive were accorded the legal status of properly sovereign bodies, this might be seen as an unequivocal move away from the unionist agenda of retaining overall power under devolution, to a more unstable model of federalism and co-sovereignty within the Union. And this option might be seen to go too far down the slope to nationalism and raise the possibility of formal secession of Scotland from the Union.

The third option is simply to do nothing. The long-term implications of that may be just as radical on the United Kingdom constitution as a whole,

"The Government believe that it is important that the decisions of the Judicial Committee of the Privy Council are binding in all legal proceedings other than proceedings before the JCPC itself. Amendment No. 292EA would mean that they were not binding upon this House, and we do not accept that position. Devolution issues will seldom be decided by this House. In normal circumstances, under Sch.6 of the Bill any devolution issue which arises in judicial proceedings in this House will be referred to the Judicial Committee unless this House considers it more appropriate that it should determine the issue itself. We think it is appropriate that this House should not be able to depart from the earlier decisions made by the JCPC. We believe that the JCPC is ideally placed to resolve disputes about vires. It has a vast experience of dealing with constitutional issues from the Commonwealth, making the provision that the JCPC's decisions of the highest status will ensure that clear decisions with a clear status are produced and that devolution issues are treated consistently. That is the advantage behind the line that we are advocating."

84 Attorney-General's Reference (No. 2 of 2001) [2004] 2 AC 72, decision of 11 December 2003, Lord Bingham of Cornhill, Lord Nicholls of Birkenhead, Lord Steyn, Lord Hoffmann, Lord Hobhouse, Lord Millett, Lord Scott of Foscote forming the majority with Lord Hope of Craighead and Lord Rodger of Earlsferry dissenting. 
however. Although, in theory, the Judicial Committee of the Privy Council may draw on a larger pool of potential judges than the House of Lords, ${ }^{85}$ in practice the devolution cases of the Privy Council have largely been decided upon by the House of Lords judges. ${ }^{86}$ When exercising this devolution jurisdiction, those judges have been acting under and in terms of the Scottish devolved constitution which, as we have seen, mandates a position of judicial supremacy over the legislature and, at least as regards the assessment of the lawfulness of the acts of the Scottish Ministers, places Westminster statutes at a normatively lower status than Convention rights. It is conceivable that this experience of acting under this Scottish constitutional model of gouvernement des juges may lead those judges to begin to question or push against the heretofore accepted tenets of the United Kingdom constitution which ascribe to judges - even in fundamental rights matters - a role subordinate to the UK Parliament. We may note in this regard, the following observations on the UK constitution made by Lord Hope (who has participated as a judge in every devolution case brought to date before the Privy Council):

"Our [UK] constitution is dominated by the sovereignty of Parliament. But Parliamentary sovereignty is no longer, if it ever was, absolute. It is not uncontrolled in the sense referred to by Lord Birkenhead LC in McCawley v The King [1920] AC 691, 720. It is no longer right to say that its freedom to legislate admits of no qualification whatever. Step by step, gradually but surely, the English principle of the absolute legislative sovereignty of Parliament which Dicey derived from Coke and Blackstone is being qualified ...

[I] $t$ is of the essence of supremacy of the law that the courts shall disregard as unauthorised and void the acts of any organ of government, whether legislative or administrative, which exceed the limits of the power that organ derives from the law. In its modern form, now reinforced by the European Convention on Human Rights and the enactment by Parliament of the Human Rights Act 1998, this principle protects the individual from arbitrary government. The rule of law enforced by the courts is the ultimate controlling factor on which our constitution is based. ..."

There is a strong case for saying that the rule of recognition, which gives way to what people are prepared to recognise as law, is itself worth calling

85 The Judicial Committee of the Privy Council exercising its devolution jurisdiction under s.103(2) of the Scotland Act may consist of Privy Councillors holding high judicial office in the United Kingdom (this means in effect all the current Inner House judges of the Court of Session) as well as the Lords of Appeal in Ordinary. By contrast the Appellate Committee of the House of Lords can only be constituted by Lords of Appeal in Ordinary or holders of high judicial office who also hold peerages (in Scotland among serving Court of Session judges, Lord Cullen of Whitekirk, Lord Mackay of Drumadoon and Lord Hardie of Blackford only).

86 Brown v Stott, 2001 SC (PC) 43 is the only case to date in which one member of the Board - Lord Kirkwood - was a Privy Councillor who was not also a Lord of Appeal in Ordinary. 
'law' and for applying it accordingly. It must never be forgotten that this rule, which is underpinned by what others have referred to as political reality, depends upon the legislature maintaining the trust of the electorate. In a democracy the need of the elected members to maintain this trust is a vitally important safeguard. The principle of parliamentary sovereignty which in the absence of higher authority, has been created by the common law is built upon the assumption that Parliament represents the people whom it exists to serve." ${ }^{\prime} 7$

The experience of the Caledonian antisyzygy may, perhaps, be seen to act as a catalyst for future radical judicial change of the uncodified constitution of the United Kingdom as a whole. The constitutional dance continues, but it may be becoming less deferential: "the rules of the game are changing", to quote the Prime Minister, ${ }^{88}$ but perhaps not in the way he had envisaged or hoped.

87 Jackson v Attorney General [2005] 3 WLR 733 per Lord Hope at pp.768, 769, 775 paras.104, 107, 126. See too similar effect the remarks by Lord Steyn at pp.767-768 para.102: "We do not in the United Kingdom have an uncontrolled constitution as the Attorney General implausibly asserts. In the European context the second Factortame decision made that clear: [1991] 1 AC 603. The settlement contained in the Scotland Act 1998 also points to a divided sovereignty. Moreover the European Convention on Human Rights as incorporated into our law by the Human Rights Act, 1998, created a new legal order. One must not assimilate the ECHR with multilateral treaties of the traditional type. Instead it is a legal order in which the United Kingdom assumes obligations to protect fundamental rights, not in relation to other states, but towards all individuals within its jurisdiction. The classic account given by Dicey of the doctrine of the supremacy of Parliament, pure and absolute as it was, can now be seen to be out of place in the modern United Kingdom. Nevertheless, the supremacy of Parliament is still the general principle of our constitution. It is a construct of the common law. The judges created this principle. If that is so, it is not unthinkable that circumstances could arise where the courts may have to qualify a principle established on a different hypothesis of constitutionalism. In exceptional circumstances involving an attempt to abolish judicial review or the ordinary role of the courts, the Appellate Committee of the House of Lords or a new Supreme Court may have to consider whether this is a constitutional fundamental which even a sovereign Parliament acting at the behest of a complaisant House of Commons cannot abolish."

88 See the Prime Minister's Press Conference for 5 August 2005, accessible on line at http://www.number-10.go vuk/output/Page8041.asp : ["W]e are today signalling a new approach to deportation orders. Let no-one be in any doubt, the rules of the game are changing. These issues will of course be tested in the courts, up to now the concern has been that orders for deportation will be struck down as contrary to Article 3 of the European Convention on Human Rights as interpreted by the European Court in the Chahal case in 1996, and indeed we have had such cases struck down. However, the circumstances of our national security have self evidently changed ... [s]o it is important to test this anew now in view of the changed conditions in Britain. Should legal obstacles arise, we will legislate further including, if necessary, amending the Human Rights Act in respect of the interpretation of the European Convention on Human Rights." 